\title{
MIMULUS GLABRATUS HBK. var. FREMONTII (Benth.) Grant
}

\section{An obscure species from the Eastern Qu'Appelle Valley, Saskatchewan}

by B. de Vries, Fort Qu'Appelle

I collected Mimulus glabratus HBK. var. Fremontii (Benth.) Grant (Fig. 1), at two separate locations in eastern Saskatchewan in the Qu'Appelle Valey on August 28 and 30, 1970. Well established. populations occur along the margin of a running stream and in a shallow rivulet rooted in mud, in =emi-shaded or open areas. The localities are as follows: \#4970 (August 28, 1970), six miles west of Round Lake, in shallow rivulet; \#4971 (August 30, 1970), 14 miles north of Whitewood, on wet margins of running tream. The voucher specimens indicated above are in the herbarium of the author.

This species ranges through North America, from Manitoba to Mexico, west to Montana, Nevada and Arizona, and it occurs in southeastern Saskatchewan at two separate localities.

Earlier reports on this species were made by Criddle, who collected the only known specimen at Aweme in Manitoba (Grant, 1924) and by Fraser ct al. (1954) and Breitung (1957) who reported on specimens from Saskatchewan. Voucher material was examined by the author and pertinent lata is as follows: Herbarium \#20629, Mimulus geyeri Torr., R. C. Russell, s. 3921, August 25, 1949. Whitewood, long stream in wooded ravine leading into the Qu'Appelle Valley; Herparium \#20628, Mimulus geyeri Torr., R. C. Russell and R. D. Tinline, August 25, 1949, Whitewood, Saskatchewan, bed of spring-fed rivulet in ravine leading into Qu'Appelle Valley. Voucher specimens are located in the Fraser Herbarium, University of Saskatchewan, Saskatoon. Another collecion is dated: Mimulus geyeri Torr., R. C. Russell and R. D. Tinline, 11-8-48, Round Lake, Whitewood, pring-fed rivulet in ravine leading nto Qu'Appelle Valley. Voucher specimen is in the Laboratory of Plant Pathology, Department of Agriculture,
Saskatoon, Saskatchewan. This specimen is revised by Breitung (Hudson, pers. comm.) to Mimulus floribundus Dougl.

The author, however, upon examining this specimen, believes it to be Mimulus glabratus var. Fremontii on basis of comparison with his own collection. Boivin (Boivin, 1964, in Cody pers. comm.) has since revised the duplicate of this specimen (\#4481, Herbarium, Canada Department of Agriculture, Ottawa) to Mimulus glabratus HBK.

The material under question is rather scanty, and although differences between Mimulus glabratus var. Fremontii and Mimulus floribundus are apparent (Grant, 1924, pp. 195, 196, and 216), they are less well defined between the species and its variety Fremontii (Grant, 1924, pp. 145, 188, and 191). Paucity of material makes determination somewhat uncertain.

It is clear that the 1949 collections came from the same area, but the collection site of the 1948 material is not clear. It is not certain whether the collectors meant "Round Lake" or "a position north of Whitewood" for their collecting station. The author assumes that all three collections came from the same general area, i.e. "Whitewood, spring-fed streamlet in ravine leading into the Qu'Appelle Valley."

These collections undoubtedly form the records on which Fraser et al. and Breitung based their listings, and it remains puzzling why Budd in his Wild Plants of the Canadian Prairies did not list the species. Perhaps the fact that Mimulus glabratus var. Fremontii occurs in rather selected (calcareous) and obscure locations plus its diminutive flowering habit, tends to make it not readily discernible in the field.

It is interesting to note that although Mimulus glabratus var. Fremontii.. is listed under various 
synonyms (Grant, 1924), the quoted data list the species under Mimulus geyeri Torr. rather than under any one of the synonyms. Hudson (pers. comm.) writes: "Doubtless it was all determined by R. C. Russell, who relied on Rydberg (Rydberg 1917) for nomenclature."

Measurements for corolla and calyx taken on \#4970 and \#4971 compare favourably on the average with those given in literature and examined voucher material for calyx, but are somewhat smaller for corolla measurements $(1.3 \mathrm{~mm}$ viz. $1.5 \mathrm{~mm})$. Measurements on calyx of fruiting material appear to conform with those given by Russell and Tinline (Hudson, pers. comm.), i.e. $.7 \mathrm{~mm}$ average.

The southeastern Saskatchewan entities could indicate a westward range extension of the species, although collections from Round Lake (\#4970) seem to be the apparent limit to such extension, as careful scrutiny revealed no additional plants west of this locality. Perhaps Mimulus glabratus var. Fremontii belongs to that group of interesting plants whose western geographic range limit apparently lies in the vicinity of Round Lake. Speculations as to whether soil, topography, or climate are the limiting factors here are set forth in a study on range extensions into southeastern Saskatchewan (de Vries, unpublished).

The systematics of the genus, as well as its history and geographical distribution are admirably discussed by Grant (1924), and the following notes are abstracted from his work. Mimulus glabratus var. Fremontii is mainly a calcophite, favouring shallow water or muddy places, often along banks of running streams, and is therefore decidedly hydrophytic. It belongs to a closely connected group which is polymorphic and plastic and has wide distribution. The plant is annual and is reproduced by seeds rather than by fragmented rooted stems. For the connoisseur of exotic foods Mimulus glabratus (and presumably its variety) is edible, and reputed to have an agreeable taste for salads or as greens cooked in soup.

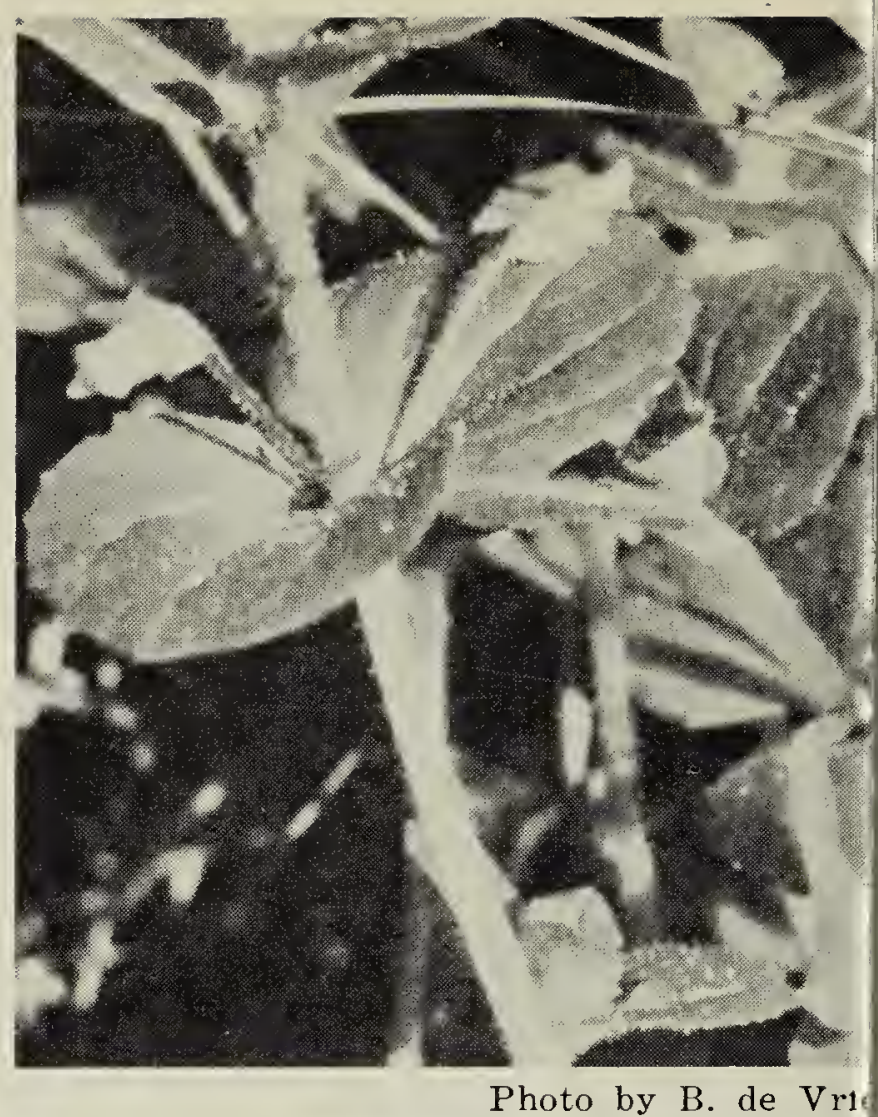

M. glabratus, \#4971, August 30, 1976

\section{Acknowledgements}

The author is grateful to R. I Tinline, Head, Plant Pathology Sed tion, Canada Department of Agricu ture, Saskatoon, Saskatchewan, for th loan of voucher material, and to Joh H. Hudson, Research Associate, Frase Herbarium, University of Saskatch wan, Saskatoon, for his helpful info mation on Mimulus collections.

The author is also indebted to $\mathrm{W}$. Cody, W. G. Dore, and J. McNe Plant Research Institute, Canada D partment of Agriculture, Ottawa, O tario, for their assistance in loanir reference material and photostat copy of voucher material.

\section{LITERATURE CITED}

Breitung, A. J. 1557. Annotated catalogue the vascular flora of Saskatchewan. T American Midland Naturalist $58: 1-72$.

de Vries, B. Unpublished. Soil, topograph and climate. The limiting factors in pla distribution. A critical review on weste range extension into south eastern Sask: chewan.

Fraser, W. P. and R. C. Russell. 1954. annotated list of the plants of Saskatch wan. Revised by R. C. Russell, G. Ledingham, and R. T. Coupland. Universi of Saskatchewan, Saskatoon, Saskatchewa $1-47$.

Grant, A. L. 1924. A monograph of the gen Mimulus. Annals of the Missouri Botani Garden $11: 99-388,10$ plates.

Rydberg, P. A. 1917. Flora of the Roc Mountains and adjacent piains. New Yo Botanical Garden. 